\title{
Psikoterapi Islam pada pecandu narkoba di Pondok Pesantren Bidayatussalikin Sleman Yogyakarta
}

\author{
Rosmaliana $^{\mathrm{a}, 1}$, Siti Bahiroh ${ }^{\mathrm{b}, 2}$ \\ a,bKomunikasi Penyiaran Islam, Fakultas Agama Islam, Universitas Muhammadiyah Yogyakarta, \\ Yogyakarta \\ *1rosmaliana255@gmail.com; 2rusman6091@yahoo.co.id \\ *Correspondent Author
}

Received: 01-02-2021

Revised: 24-07-2021

Accepted: 09-08-2021

\section{KATAKUNCI}

narkoba;

pondok pesantren;

psikoterapi Islam
KEYWORDS

drugs;

Islamic boarding school; Islamic psychotherapy
ABSTRAK

Salah satu upaya yang dilakukan pemerintah untuk mengatasi maraknya kasus narkoba adalah dengan rehabilitasi. Sejauh ini pemerintah banyak melakukan kerjasama dengan berbagai pusat rehabilitasi, salah satunya yayasan pondok pesantren Bidayatussalikin dengan metode yang relatif berbeda dari metode yang digunakan oleh pusat rehabilitasi pada umumnya, yaitu dengan pendekatan psikoterapi Islam. Oleh karena itu, penelitian ini bertujuan menjelaskan proses, manfaat, dan faktor pendukung serta penghambat proses psikoterapi Islam yang dilakukan pondok pesantren Bidayatussalikin, kepada santri (korban penyalahgunaan narkoba). Metode yang digunakan pada penelitian ini adalah kualitatif dengan pendekatan studi kasus. Penelitian ini dilakukan di pondok pesantren Bidayatussalikin Sleman Yogyakarta yang sudah bekerja sama dengan BNN (Badan Narkotika Nasional) dengan informan kunci yaitu terapis sekaligus pendiri pondok pesantren, konselor, musyrif, serta santri. Pengumpulan data dilakukan dengan wawancara, observasi, dan dokumentasi. Berdasarkan hasil penelitian, maka penelitian ini menyimpulkan bahwa proses psikoterapi Islam yang dilakukan di pondok pesantren Bidayatussalikin menggunakan pendekatan tasawuf yang meliputi takhalli, tahalli dan tajalli. Penelitian ini juga menyimpulkan bahwa manfaat psikoterapi Islam diantaranya, perkembangan fisik santri menjadi lebih baik, gangguan kecemasan para santri mulai menurun, santri dapat bersosialisasi dengan lingkungan, dan santri menjadi taat beribadah kepada Allah SWT. Selanjutnya faktor pendukung prosesi psikoterapi Islam adalah memiliki terapis yang ahli dalam bidangnya, serta sarana dan prasarana yang memadai. Sebaliknya, faktor penghambat proses psikoterapi Islam dikarenakan peran orang tua yang kurang konsisten dan karakter beberapa santri kurang baik.

\section{Islamic Psychotherapy for the drug addicts of Bidayatussalikin Islamic Boarding School}

One of the efforts made by the government to overcome the rampant drug cases is rehabilitation. So far, the government has collaborated a lot with various rehabilitation centers, one of which is the Bidayatussalikin Islamic boarding school foundation with a method that is relatively different from the method used by rehabilitation centers in general, namely the Islamic psychotherapy approach. Therefore, this study aims to explain the process, benefits, and 
supporting and inhibiting factors of the Islamic psychotherapy process carried out by the Bidayatussalikin Islamic boarding school, to students (victims of drug abuse). The method used in this research is qualitative with a case study approach. This research was conducted at the Bidayatussalikin Islamic boarding school, Sleman Yogyakarta, which has collaborated with the National Narcotics Agency with key informants, namely therapists and founders of Islamic boarding schools, counselors, musyrif, and students. Data collection is done by interview, observation, and documentation. Based on the results of the study, this study concludes that the Islamic psychotherapy process carried out at the Bidayatussalikin Islamic boarding school uses a Sufism approach which includes takhalli, tahalli and tajalli. This study also concludes that the benefits of Islamic psychotherapy include better physical development of students, students' anxiety disorders begin to decrease, students can socialize with the environment, and students become obedient to worship Allah SWT. Furthermore, the supporting factors for the Islamic psychotherapy procession are having therapists who are experts in their fields, as well as adequate facilities and infrastructure. On the other hand, the inhibiting factor for the Islamic psychotherapy process is due to the inconsistent role of parents and the poor character of some students.

This is an open-access article under the CC-BY-SA license.

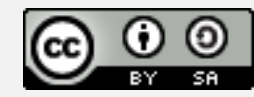

\section{Pendahuluan}

Narkoba atau narkotika adalah suatu zat atau obat yang berasal dari tanaman atau bukan tanaman baik sintesis maupun semi sintesis. Narkotika dapat mempengaruhi kesadaran seseorang, seperti mengurangi atau hilangnya rasa, bahkan menghilangkan rasa nyeri yang dapat menumbuhkan kecanduan secara berlebihan (BNN, 2019). BNN pada tahun 2017 mencatat angka prevalensi penyalahgunaan narkotika yaitu sebesar $1,77 \%$ atau setara dengan 3.376.115 orang, setara pada usia 10-59 tahun. Pada tahun 2018 prevalensi angka penyalahgunaan narkoba di kalangan pelajar di tiga belas ibu kota provinsi di Indonesia mencapai angka 3,2\% atau setara dengan 2,29 juta orang. Kemudian di tahun 2019, Kepala BNN Komjen Pol Heru Winarko menjelaskan meningkatnya peredaran narkoba selama tahun 2019 dari tahun sebelumnya sebesar 0,3\% kurang lebih 3,6 jiwa dan paling banyak usia 1565 tahun (Fra, 2020).

Berdasarkan UU tentang narkoba No. 35 tahun 2009 pasal 1 no 13, pecandu narkoba adalah orang yang memakai atau menyalah gunakan narkotika dengan kondisi ketergantungan pada narkoba baik secara fisik maupun psikis dan harus menjalankan proses rehabilitasi di balai atau panti sosial. Pada proses rehabilitasi yang dijalani, para pecandu narkoba akan diasingkan terlebih dahulu dari interaksi sosial dan lingkungannya. Hal ini dimaksudkan agar pecandu narkoba dapat fokus menjalankan aktivitas di panti rehabilitasi dan terhindar dari bujuk rayu seseorang untuk kembali menggunakan narkoba.

Adapun hasil penelitian BNNP (Badan Narkotika Nasional Provinsi) menerangkan bahwa DIY menempati peringkat lima besar provinsi rawan narkoba di Indonesia. Korban pengguna narkoba kebanyakan dari kalangan pelajar dan mahasiswa. Sementara jenis terbanyak yang dikonsumsi oleh pengguna narkoba adalah sabu-sabu, ganja hingga tembakau gorilla (Rel, 2020). Maraknya kasus narkoba hingga saat ini merupakan permasalahan yang perlu dan penting untuk diatasi, hal ini berkaitan dengan dampak dari penggunaan narkoba itu sendiri. 
Yurliani (dalam Nainggolan, 2011) menjelaskan akibat dari penyalahgunaan narkoba dapat berdampak pada aspek fisik, psikologis (mental emosional) dan sosial. Gangguan yang terjadi pada tiga aspek ini dapat membentuk perubahan perilaku menjadi sindrom amotivasional, depresi dan kecemasan sosial. Pada aspek fisik dapat menganggu kondisi otak dan tubuh secara umum, adanya perubahan sel saraf di dalam otak, kemudian dehidrasi, hilang ingatan, halusinasi serta kejang hingga kematian. Dampak yang ditimbulkan oleh narkoba pada pecandu begitu mengerikan, kondisi pada dirinya membawa marabahaya. Dengan demikian diperlukan adanya proses rehabilitasi agar korban penyalahgunaan narkoba memiliki kesempatan untuk berjuang kembali dalam menjalani hidup yang lebih sehat tanpa adanya zat-zat adiktif.

Upaya yang dilakukan oleh pemerintah untuk menanggulangi penyalahgunaan narkoba diperlukan secara terpadu dan komprehensif yang meliputi usaha preventif, represif, terapi dan rehabilitasi. Namun sejauh ini, upaya penanggulangan narkoba tidak hanya dilakukan oleh pemerintah saja, melainkan juga yayasan mandiri seperti pondok pesantren. Seperti yang disampaikan oleh Khamim (2018) bahwa metode yang dilakukan oleh pondok pesantren dalam membina korban penyalahgunaan narkoba dapat dilakukan dengan metode studi kasus, metode pembiasaan, meliputi, sholat, membaca al-qur'an metode wirid, metode sorogan, serta metode kebebasan. Selain itu, yayasan pondok pesantren membuka tempat rehabilitasi narkoba dengan pendekatan psikoterapi islam dan spiritual.

Psikoterapi Islam menurut Adz Dzaky (2001) adalah metode pengobatan atau penyembuhan pada gangguan penyakit dengan bimbingan serta pengajaran Allah SWT, malaikat, nabi, rasul dan para ahli waris nabi. Terapi ini dapat mengobati penyakit seperti mental, spiritual maupun fisik dengan berpedoman pada Al-Qur'an dan Sunnah Nabi Muhammad SAW. Pada saat ini psikoterapi Islam menjadi salah satu disiplin ilmu yang berdiri sendiri, namun demikian tetap saling terkait ke bentuk-bentuk studi Islam lainnya seperti psikologi Islam, tradisi sufi, dakwah, pendidikan, teologi, ataupun etika. Literatur psikoterapi Islam biasanya berfokus pada interpretasi dan penerapan berbagai teori dan teknik konseling berbasis Barat bersama dengan sumber-sumber dalam tradisi Islam (Isgandarova, 2012; Isgandarova \& O'Connor, 2012; Keshavarzi \& Haque, 2013; Sabry \& Adarsh, 2013)

Selanjutnya, salah satu pondok pesantren di Yogyakarta yang memberikan fasilitas rehabilitasi berbasis islami seperti terapi dan relaksasi adalah pondok pesantren Bidayatussalikin. Pondok pesantren Bidayatussalikin turut menangani korban (santri) yang terjerumus narkoba dan mengalami kenakalan remaja. Metode yang diberikan oleh pondok pesantren sesuai dengan kondisi fisik dan mental para pecandu narkoba. Artinya, para santri dibekali dengan ilmu aqidah dan akhlaq sesuai ajaran sunnah rasul. Pondok Pesantren Bidayatussalikin menerapkan suatu bentuk bimbingan keagamaan pada santri, agar korban penyalahgunaan narkoba tidak hanya sembuh secara medis ataupun psikologis saja, melainkan "Bidayatussalikin" yang berarti, orang yang mendekatkan diri kepada Allah, memiliki kepribadian yang religius.

Berdasarkan uraian di atas, peneliti tertarik untuk mengkaji lebih dalam tentang proses psikoterapi, serta apakah psikoterapi islam dapat mengatasi santri khusunya pada korban penyalahgunaan narkoba dan menjelaskan faktor pendukung maupun penghambat psikoterapi islam di Pondok Pesanten Bidayatussalikin Sleman Yogyakarta. Mengingat masih minimnya penelitian terdahulu tentang psikoterapi islam. Sejauh ini penelitian yang pernah dilakukan oleh peneliti terdahulu yaitu yang dilakukan oleh Pristiwiyanto (2010), dimana peneitian berfokus pada penyembuhan depresi korban penyalahgunaan narkotika.

Metode yang dilakukan Pristiwiyanto (2010) untuk penyembuhan depresi mental korban penyalahgunaan narkoba dimulai dari penyembuhan aspek spiritual. Metode yang digunakan pada penelitian tersebut merupakan landasan dalam upaya penyembuhan aspek biologis, psikis dan sosial pada penderita. Proses penyembuhan dilakukan melalui tiga tahap, 
yaitu yang pertama proses pembersihan diri dari kotoran jiwa, dengan mandi taubat. Kemudian kotoran raga (racun narkotika) dilakukan dengan meminum seperti ramuan yang terdiri dari madu, telor dan degan (kelapa muda) hijau. Proses penanaman landasan spiritual dilakukan melalui talqin (kalimat tauhid=Lailahailallah) pada diri penderita. Kemudian yang ketiga, pembiasaan menjalankan aktifitas ibadah seperti sholat dan dzikir yang didahului dengan mandi besar (Pristiwiyanto, 2010). Oleh karena itu, penelitian ini diharapkan dapat bermanfaat bagi pengembangan ilmu, khususnya di bidang ilmu Psikologi ataupun pada masyarakat sekitar tentang peranan dari psikoterapi Islam. Penelitian ini juga diharapkan dapat membantu serta menambah pemahaman dan menjadikan solusi yang konkret bagi para pecandu narkoba untuk menggunakan pondok pesantren sebagai alternatif dalam mengatasi permasalahan pecandu narkoba yang ada di Indonesia.

\section{Metode}

Pendekatan yang digunakan pada penelitian sesuai dengan tujuan penelitian yaitu menggunakan metode kualitatif. Peneliti menggunakan desain studi kasus di Pondok Pesantren Bidayatussalikin Sleman Yogyakarta. Partisipan pada penelitian ini adalah pendiri sekaligus terapis, konselor, musyrif (pembina santri), serta santri pondok pesantren Bidayatussalikin Sleman Yogyakarta. Penelitian dilakukan dalam rentang waktu kurang lebih satu bulan, 6 November sampai dengan 9 Desember 2020.

Teknik pengumpulan data yang digunakan adalah wawancara, observasi, dan dokumentasi. Pengambilan data dengan menggunakan metode wawancara dilakukan secara langsung kepada pendiri dan sekaligus terapis pondok pesantren Bidayatussalikin. Selanjutnya satu orang konselor yang mengetahui latar belakang santri, dua orang musyrif santriawan yang telah membina serta membimbing kegiatan santri, dan yang terakhir adalah lima orang santri korban penyalahgunaan narkoba yang sedang menjalani proses rehabilitasi dengan tingkat keparahan tinggi, dan saat ini sudah berada ditahap kontemplasi. Selanjutnya, observasi secara langsung terhadap proses yang dilakukan oleh pondok pesantren terhadap santri korban penyalahgunaan narkoba. Kemudian metode yang ketiga adalah dokumentasi. Dokumentasi dalam hal ini berhubungan dengan dokumen tertulis terkait dengan sejarah, visi, misi, dan hal lain yang berkaitan dengan psikoterapi Islam yang dilakukan di pondok pesantren Bidayatussalikin. Analisis data dalam penelitian ini menggunakan model Miles, Huberman, dan Saldana (2014) yaitu reduksi data, penyajian data, dan penyusunan kesimpulan.

\section{Hasil}

Berdasarkan hasil wawancara kepada pendiri pondok pesantren sekaligus terapis, satu orang konselor, dua pembina santri (musyrif), dan lima orang santri diperoleh data bahwa proses psikoterapi Islam yang dilakukan di pondok pesantren Bidayatussalikin dalam rangka membina akhlak santri, khususnya pada penyembuhan korban penyalahgunaan narkoba. Adapun yang dilakukan oleh pondok pesantren menggunakan pendekatan tasawuf, yaitu melalui tiga tahap: 1) takhalli (pengendalian diri); 2) tahalli (pembersihan diri); 3) tajjali (pengembangan kontrol diri).

Proses pertama takhalli (pengendalian diri) menurut pendiri sekaligus terapist dilakukan dengan memberikan bimbingan kepada santri melalui bentuk penyatuan santri kepada Allah Subhanahu wa Ta'ala. Hal tersebut dilakukan karena ketauhidan kepada Allah merupakan suatu hal yang paling penting sebelum melaksanakan kegiatan beribadah, dalam hal ini adalah mandi taubat atau berendam. Menurut SOP, mandi taubat dilaksanakan pada pukul 03.00 WIB dan dilakukan paling sedikit selama 15 menit atau tergantung gangguan penyalahgunaan zat. Tahapan kedua tahalli (pembersihan diri), yaitu dengan beribadah kepada Allah seperti melaksanakan shalat wajib maupun sunnah, dzikir, dan melaksanakan puasa sunnah. Tahapan terakhir adalah tajjali (pengembangan kontrol diri) adalah tausiyah 
oleh pihak pondok pesantren Bidayatussalikin Sleman, kegiatan riyadhah dan pembinaan ketrampilan. Tausiyah diisi oleh musyrif Pondok Pesantren dengan kitab riyadhussalihin dan dimulai dari setelah sholat dhuha sampai setelah sholat isya.
"Kegiatan setelah sholat shubuh adalah membaca Al-Qur'an dilanjutkan dzikir haqqul yaqin, setelah sholat dhuha saya mengisi kitab riyadhussalihin bab keikhlasan, setelah sholat dhuhur dilanjut bab larangan, setelah sholat ashar bab amalan surah Al-Waqiah dan dilanjut dengan membaca Al-Qur'an dengan terjemaahan perkata atau per ayat, banyak kok yang mampu menghafal tergantung latar pendidikan nya saja atau yang masih iqro ya baca iqro dan juz amma bagi santri yang masih membaca juz amma. Pada sholat magrib murojaah al-qur'an, terakhir setelah sholat isya di lanjutkan bab riyadhussalihin namun dengan tema yang berbeda".
(Wawancara musyrif, Bapak NR, Jum'at 6 November 2020, pukul 13.26 WIB).

Banyak manfaat dari perjalanan riyadhah program eksternal yang diadakan oleh pondok pesantren Bidayatussalikin. Seperti yang disampaikan oleh pendiri, bahwasanya dengan membantu orang lain yang sedang membutuhkan pertolongan dapat membuat orang yang memberikan bantuan memiliki emosi positif, yaitu merasa tenang dan bersyukur.

\begin{abstract}
"Ketika melakukan riyadhoh ini, perasaan jadi tenang, rasa syukur kita melihat kehidupan, melihat masyarakat sekitar. Saling membantu orang yang sedang membutuhkan kita".
\end{abstract}

(Wawancara dengan pendiri-terapist, Kiyai D, Selasa, 8 Desember 2020. Pukul 13.30 WIB).

Berikutnya, tahap terakhir dari tajjali adalah pembekalan ketrampilan, selain pembekalan dalam hal keimanan dan ketaqwaan Islam. Pondok Pesantren Bidayatussalikin memberikan pembinaan ketrampilan kepada santri dengan cara membimbing untuk mengembangkan bakat santri di beberapa bidang seperti perikanan, perkebunan, pertukangan, perbengkelan dan pengelasan, anyaman bambu, dan lain sebagainya.

Berdasarkan hasil wawancara juga menunjukan adanya manfaat yang diperoleh dari proses psikoterapi, diantaranya kondisi fisik, psikis, spiritual dan sosial santri yang berkembang menjadi lebih baik secara perlahan, mengurangi bahkan menghilangkan ketergantungan santri terhadap konsumsi narkoba, santri dapat bersosialisasi dengan lingkungan, dan santri menjadi taat beribadah kepada Allah Subhanahu wa Ta'ala. Hal tersebut sesuai dengan yang disampaikan oleh salah satu santri pada saat wawancara, bahwa pada awal masuk pesantren kondisi fisik dari santri D kurus dan kehilangan nafsu makan disebabkan konsumsi narkoba. Secara psikologis D merasakan adanya gangguan kecemasan, halusinasi dan takut menjadi gila. Sementara kondisi spiritual D pada awal masuk pesantren tidak pernah sholat, mengaji ataupun melakukan ritual ibadah lainya. Selanjutnya secara sosial santri D merasa diasingkan oleh keluarga maupun tetangganya. Namun setelah santri diberikan psikoterapi Islam, fisik D kembali sehat, sudah tidak mengalami gangguan kecemasan maupun halusinasi, dan secara spiritual santri D semakin dekat dan muncul ketauhidan kepada Allah, dapat melakukan ibadah shalat, puasa, serta mengaji seperti saat ini yang sudah terbiasa dilakukan.

"Saya tidak menyangka mba bisa ngaji, saya seumur-umur baru bisa ngaji disini. Dari mulai iqro 1-6 sampai bisa ke Al-qur'an itu menurut saya suatu keajaiban. Sekarang saya lebih suka ngaji mba, karena baca Al-qur'an itu seperti obat hati. Saya suka sedih sampai merinding kalo baca surat Ar-Rahman artinya benar-benar membuat perasaan saya merinding" (Wawancara dengan D, Jum'at, 6 November 2020 Jam 10.30) 
Proses psikoterapi Islam juga memiliki faktor pendukung dan penghambat, Faktor pendukung menurut konselor adalah adanya peran terapis sekaligus pendiri yang memiliki ilmu dan sikap kedisiplinan tinggi. Selain itu, sarana dan prasarana pondok pesantren yang juga turut mendukung proses terapi, seperti fasilitas pendukung gedung SOP (Standar Operasional Prosedur) rehabilitasi, kolam untuk berendam, ruang konseling, ruang bermain, tempat olahraga seperti lapangan futsal, ruang diskusi FGD (family group discussion) maupun transportasi seperti mobil penjemputan. Sedangkan faktor penghambat dari proses psikoterapi Islam berasal dari faktor eksternal, dalam hal ini diantaranya berhubungan dengan peran orang tua. Orang tua menjadi salah satu faktor penghambat dikarenakan diantaranya ada yang kurang konsisten dengan kesepakatan yang telah dibuat bersama pondok pesantren Bidayatussalikin. Faktor penghambat selanjutnya adalah karakteristik santri yang kurang baik, yaitu ketika santri pandai bermain watak seperti berbohong di depan para konselor dan musyrif.

\section{Pembahasan}

Proses psikoterapi Islam dalam pendekatan tasawuf yang dilakukan oleh pondok pesantren Bidayatussalikin memiliki tiga (3) tahap, yaitu seperti berikut:

1. Takhalli (pengendalian pada diri)

Psikoterapi Islam pada pondok pesantren Bidayatussalikin yang paling utama adalah dalam pengendalian diri, yaitu pada aspek religiusitas dalam hal ini pentingnya ketauhidan dalam beragama. Seseorang harus meyakini adanya Allah Subhanahu Wa Ta'ala, kemudian terapi yang selanjutnya adalah mandi taubat atau berendam di kolam mata air ainun hayat atau di sungai dan diikuti dengan berdzikir.

2. Tahalli (pembersihan pada diri)

Proses pembersihan diri, maksudnya adalah ketika santri sudah disiapkan untuk memulai beribadah maka pembersihan diri ini diisi dengan rutinitas ibadah sesuai anjuran Rosulullah Shallallahu 'Alaihi Wa Sallam. Pertama, melaksanakan shalat lima waktu, ditambah dengan shalat sunnah qabliyah dan ba'dhiyah, shalat dhuha dan shalat tahajud. Kedua, berdzikir menyebut nama Allah Subhanahu Wa Ta'ala agar senantiasa diberikan ketenangan hati. Selanjutnya, untuk menahan hawa nafsu maka santri dibimbing untuk berpuasa sunnah seperti Senin-Kamis.

3. Tajjali (pengembangan kontrol pada diri)

Proses tajjali merupakan pengembangan pada diri, dimana santri mengembangkan dirinya dengan diisi siraman rohani atau tausiyah dari Kiyai maupun musyrif. Prosesi riyadhah merupakan cara bersyukur kepada Allah Subhanahu wa Ta'ala yaitu latihan olahraga dengan berjalan kaki, jarak yang ditempuh cukup jauh biasanya dari kota ke kota bertujuan saling membantu sesama manusia di sepanjang jalan. Selain itu, perjalanan ke bukit dan gunung yang akan membuat santri merasakan ketenangan hati ketika sudah berada di puncak dengan sejuknya udara yang dirasakan, dan cara bersyukur menikmati alam dari Sang Pencipta. Kemudian yang terakhir yaitu pembinaan ketrampilan, santri diberikan pembinaan ketrampilan seperti perkebunan, perikanan, peternakan, perbengkelan dan pengelasan dan lain sebagainya. Tujuannya agar santri dapat bermanfaat bagi satu dan lainnya.

Hasil penelitian ini didukung oleh penelitian terdahulu yang dilakukan Hawi (2018) dengan tujuan mengobati para pecandu narkoba. Penelitian yang dilakukan oleh Hawi dilakukan melalui rehabilitiasi integratif kepada para remaja pecandu narkoba di Pondok Proses rehabilitasi ini dilakukan dengan mengintegrasikan model terapi fisiologis berbasis medis, terapi moral yang berbasis spiritual kemudian diikuti dengan interaksi sosial, serta ketrampilan hidup (life skill) sebagai bekal dalam menjalani prosesi pasca rehabilitasi. Dimulai dengan penyembuhan gangguan fisik, kemudian psikis, yang dilanjutkan dengan mengisi jiwa pecandu dengan nilai spiritual agar dapat menumbuhkan transendensi untuk 
meraih kehidupan yang religius, sehat, kreatif serta dapat terhindar dari pengaruh sosial yang negatif (Hawi, 2018).

Manfaat Psikoterapi Islam yang sudah dilakukan kepada santri, khususnya pecandu narkoba yaitu adanya perkembangan fisik menjadi lebih baik. Kedua, gangguan kecemasan dari para santri mulai menurun. Ketiga, santri dapat bersosialisasi dengan lingkungannya. Terakhir keempat, santri menjadi taat beribadah kepada Allah Subhanahu Wa Ta'ala. Berdasarkan manfaat tersebut terlihat bahwa psikoterapi Islam yang dilaksanakan di pondok pesantren Bidayatussalikin menawarkan kepada muslim yang taat untuk dapat menggunakan layanan psikoterapi yang selama ini banyak dihindari karena diasumsikan tidak melibatkan nilai-nilai agama. Artinya, penelitian ini juga turut mendukung kesimpulan yang ditawarkan Rothman dan Coyle (2020) bahwa psikoterapi merupakan salah satu bentuk wawasan baru dalam pengembangan intervensi klinis dalam psikoterapi Islam.

Disamping keberhasilan proses psikoterapi Islam, adanya faktor pendukung yaitu peran terapis yang memiliki ilmu terhadap proses psikoterapi Islam dan memiliki sikap kedisiplinan tinggi. Kemudian sarana dan prasarana yang mendukung untuk melaksanakan proses psikoterapi Islam. Selanjutnya faktor penghambat berasal dari faktor eksternal, diantaranya peran orang tua yang kurang konsisten pada kesepakatan Pondok Pesantren Bidayatussalikin. Faktor penghambat selanjutnya adalah karakteristik santri yang kurang baik, yaitu ketika santri pandai bermain watak di depan para konselor dan musyrif seperti pada saat wawancara, dimana santri membolak balikan fakta atau berbohong. Berdasarkan hal tersebut memperlihatkan bahwa rehabilitasi, khususnya bagi remaja pecandu narkoba merupakan bentuk kerjasama dan tanggung jawab antar berbagai macam pihak. Hal ini sesuai dengan yang disampaikan oleh Noegroho, Sulaiman, dan Suryanto (2018) bahwa proses rehabilitasi narkoba merupakan tanggung jawab Bersama antar keluarga, kerabat, teman dekat, BNN, lembaga sosial, serta pendidikan dan keagamaan.

\section{Simpulan}

Penelitian ini menunjukan bahwa proses psikoterapi Islam yang diberikan Pondok Pesantren Bidayatussalikin Sleman Yogyakarta mencakup tiga proses. Proses pertama takhalli, yakni pengendalian diri terkait dengan aspek religiusitas dalam hal ini melalui ketauhidan, selanjutnya mandi taubat atau berendam. Kedua, tahalli yaitu pembersihan pada diri, meliputi ibadah shalat, dzikir, dan puasa. Proses ketiga adalah tajjali, yaitu proses pengembangan kontrol pada diri melalui tausiyah, riyadhah dan pembinaan ketrampilan meliputi perkebunan, peternakan, perikanan, dan perbengkelan. Penelitian ini juga menyimpulkan bahwa manfaat dari psikoterapi Islam dalam upaya penyembuhan santri pada korban penyalahgunaan narkoba, yang pertama adalah adanya perkembangan fisik menjadi lebih baik; kedua, gangguan kecemasan dari para santri mulai menurun; ketiga, santri dapat bersosialisasi dengan lingkungannya; dan yang keempat, santri menjadi taat beribadah kepada Allah Subhanahu Wa Ta'ala. Sementara faktor pendukung pada proses psikoterapi Islam adalah peran terapis yang memiliki ilmu yang berhubungan dengan proses psikoterapi Islam, selain itu memiliki sikap kedisiplinan yang tinggi. Faktor lainnya adalah sarana dan prasarana yang mendukung proses pelaksanaan psikoterapi Islam. Sedangkan faktor penghambat keberhasilan proses berkaitan dengan peran orang tua yang kurang konsisten dengan aturan yang disusun oleh Pondok Pesantren Bidayatussalikin. Faktor penghambat lainnya adalah karakteristik santri yang kurang baik yaitu tidak jujur pada saat proses dilaksanakannya terapi

\section{DAFTAR PUSTAKA}

Adz-Dzaky, M. H. B. (2001). Psikoterapi \& konseling Islam. Yogyakarta: Fajar Pustaka Baru. 
BNN. (2019, Januari 7). Pengertian narkoba dan bahaya narkoba bagi kesehatan. Retrieved from Badan Narkotika Nasional Republik Indonesia: https://bnn.go.id/pengertiannarkoba-dan-bahaya-bagi-kesehatan/.

Fra, R. (2020, Juni 26). Wapres: Pengguna narkoba naik, generasi milenial rentan kena. Retrieved from CNN Indonesia. https//m.cnnindonesia.com/nasional/ 20200626132039-20-517818/wapres-pengguna-narkoba-naik-generasi-milenialrentan-kena.

Hawi, A. (2018). Remaja pecandu narkoba: Studi tentang rehabilitasi integratif di panti rehabilitasi narkoba Pondok Pesantren Ar-Rahman Palembang. Tadrib, 4(1), 99-119. https://doi.org/10.19109/Tadrib.v4i1.1958.

Isgandarova, N. (2012). Effectiveness of Islamic spiritual care: Foundations and practices of Muslim spiritual care givers. Journal of Pastoral Care and Counseling, 66(3), 1-14. https://doi.org/10.1177/154230501206600304.

Isgandarova, N., \& O'Connor, T. (2012). A redefinition and model of Canadian Islamic spiritual care. Journal of Pastoral Care and Counseling, 66(2), 1-8. https://doi.org/10.1177/ 154230501206600207.

Keshavarzi, H., \& Haque, A. (2013). Outlining a psychotherapy model for enhancing Muslim mental health within an Islamic context. The International Journal for the Psychology of Religion, 23, 230-249. https://doi.org/10.1080/10508619.2012.712000.

Khamim, N. (2018). Pondok pesantren dan penanggulan narkoba di Indonesia. Attaqwa, Vol. $14,36-54$.

Miles, M. B., \& Huberman, A. M. \& Saldana. J. (2014). Qualitative data analysis, A methdos Sourcebook. Edition, 3.

Nainggolan, T. (2017). Hubungan antara kepercayaan diri dengan kecemasan sosial pada pengguna NAPZA: Penelitian di Balai Kasih Sayang Parmadi Siwi. Sosio Konsepsia, 16. 2: 161-174.

Noegroho, A., Sulaiman, A. I., \& Suryanto, S. (2018). Religious counseling as an informal education approach in rehabilitation of drug addicts. International Educational Research, 1(2), 57-57. https://doi.org/10.30560/ier.v1n2p57.

Pristiwiyanto, P. (2010). Psikoterapi Islami ala Pondok Pesantren Suryalaya Surabaya sebagai alternatif penyembuhan depresi korban penyalahgunaan narkotika. Fikroh: Jurnal Pemikiran dan Pendidikan Islam, 4(1), 72-91.

Pemerintah Pusat. Undang-undang (UU) tentang Narkotika. LN. 2009/ No. 35, TLN NO. 5062, LL SETNEG: 58 HLM. https://peraturan.bpk.go.id/.

Rel, T. (2020, Februari 12). Yogyakarta peringkat lima besar provinsi rawan narkoba. Retrieved from Tobasatu.com: https://www.tobasatu.com/2020/02/12/yogyakartaperingkat-lima-besar-provinsi-rawan-narkoba/.

Rothman, A., \& Coyle, A. (2020). Conceptualizing an Islamic psychotherapy: A grounded theory study. Spirituality in Clinical Practice, 7(3), 197. https://doi.org/10.1037/scp0000219.

Sabry, W. M., \& Vohra, A. (2013). Role of Islam in the management of psychiatric disorders. Indian Journal of Psychiatry, 55(6), S205-S214. https://doi.org/10.1037/scp0000219. 